\title{
RECENZJE WYDAWNICZE PODRECCZNIKA ANTONIEGO SMOLUKA PT. „ALGEBRA LINIOWA”
}

\author{
Marian Matłoka \\ Uniwersytet Ekonomiczny w Poznaniu
}

DOI: $10.15611 / \mathrm{dm} .2016 .13 .08$.

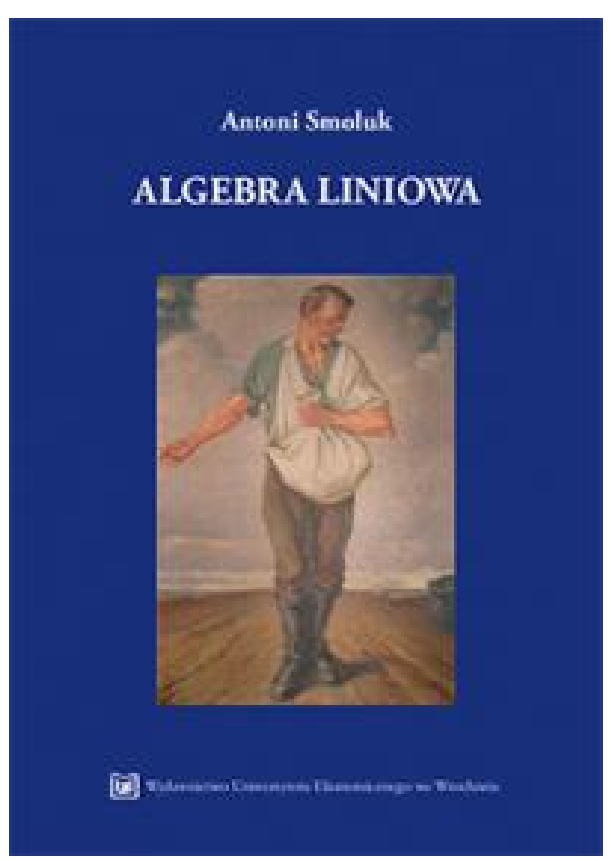

Recenzowany podręcznik „Algebra liniowa” przeznaczony jest przede wszystkim dla studentów. Uważam jednak, że każdy nauczyciel i wykładowca algebry liniowej powinien się z nim zapoznać. Na ponad 220 stronach Autor prezentuje wiadomości z zakresu logiki, relacji, przestrzeni liniowych, macierzy, wyznaczników, układów równań i form kwadratowych. Dobór materiału, jak i sposób jego prezentacji pokazują, że Autor jest wytrawnym dydaktykiem. Po wprowadzeniu kolejnych pojęć czy twierdzeń pojawiają się starannie przygotowane stosowne wykresy, tabele, rysunki, przykłady objaśniające istotę podanych definicji czy faktów i służące ich utrwaleniu w pamięci czytelnika. Niewątpliwą zaletą podręcznika jest także zawartość i spójność poszczególnych rozdziałów, w których nie ma rzeczy zbędnych.

Zaprezentowane przez Autora podejście do przedstawionych w podręczniku zagadnień jest $\mathrm{w}$ wielu przypadkach różne od spotykanych w dotychczasowych podręcznikach. Właśnie to odmienne spojrzenie na problemy algebry liniowej powoduje, że recenzowana pozycja jest nie tylko podręcznikiem akademickim, lecz również cenną pozycją naukową. 
Recenzowany podręcznik jest zgodny z programem nauczania, a jego przydatność do procesu dydaktycznego nie podlega dyskusji. Stanowi on bardzo cenną i wyróżniającą się pozycję wśród podręczników z algebry liniowej.

Uważam, że przedstawiony mi do recenzji podręcznik spełnia wszystkie wymagania stawiane przez Wydawnictwo tego typu pozycjom. Jestem głęboko przekonany, że znajdzie on uznanie u czytelników zainteresowanych problematyką algebry liniowej.

Poznań, dnia 21 września 2016 r.

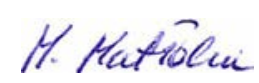

\section{$* * *$ \\ Jerzy Mika \\ Uniwersytet Ekonomiczny w Katowicach}

\section{Podstawa opracowania recenzji}

Umowa o dzieło NR/W-330-1-562/2016 zawarta w dniu 08.09.2016 r. pomiędzy Uniwersytetem Ekonomicznym we Wrocławiu, reprezentowanym przez Prorektora ds. Nauki prof. zw. dr. hab. Jerzego Niemczyka, a recenzentem.

\section{Zakres recenzowanego opracowania}

Pierwowzorem opiniowanego dzieła jest wydany w roku 2007 przez Wydawnictwo Akademii Ekonomicznej we Wrocławiu podręcznik naukowy „Podstawy algebry liniowej” napisany przez Profesora Antoniego Smoluka, przy czym przedstawiona nowa wersja jest autentycznie twórczym rozszerzeniem i logicznym uzupełnieniem pierwowzoru. Przedstawione do recenzji dzieło składa się z wprowadzenia, piętnastu rozdziałów oraz skorowidza nazw, indeksu nazwisk, wykazu użytych symboli i spisu literatury pomocniczej. Treść podręcznika obejmuje pełny zakres problemów związa- 
nych z współcześnie rozumianym pojęciem algebry liniowej. Merytorycznym wstępem formalnym do treści zasadniczych, a jednocześnie olśniewającym swym pięknem ,traktatem filozoficznym o genezie i istocie algebry liniowej" jest autorska przedmowa będąca przekonywającym wprowadzeniem zawierającym znakomicie dobrane i precyzyjnie przedstawione uwagi i objaśnienia, mające ułatwić czytelnikom dobre zrozumienie treści przedstawionego tekstu i intencji Autora. Zgodnie z przyjętą koncepcją kompozycji całości opracowania w następnej kolejności przedstawiono rozdziały dotyczące poszczególnych odrębnych sfer merytorycznych. W tym zakresie Autor każdorazowo na wstępie kreśli genezę rozpatrywanego zagadnienia szczegółowego, a następnie precyzyjnie i wyczerpująco, lecz zwięźle i bez elementów zbędnych wyjaśnia meritum podjętej tematyki. Wszędzie tam, gdzie jest to zasadne, Autor posługuje się starannie dobranymi przykładami bezpośrednio lub pośrednio związanymi z interpretacją, najczęściej ekonomiczną, rozpatrywanej problematyki. Tekst poszczególnych rozdziałów jest też pełen uwag i odniesień filozoficznych, historycznych i metodologicznych. Ponadto każdy rozdział kończy doskonale dobrany zestaw zadań do samodzielnego rozwiązania przez czytelników oraz odpowiedzi i ewentualnie dodatkowe wskazówki i komentarze. Zasadniczą treść pracy uzupełniono starannie opracowanymi, reprezentatywnymi i właściwie zredagowanymi elementami graficznymi.

W związku z powyższą wstępną charakterystyką ogólną opiniowanej monografii stwierdzam, że, moim zdaniem, Autor przedstawił tekst o jasno określonej i wyraźnie wyodrębnionej tematyce, podporządkowany ostro zarysowanej i silnie zindywidualizowanej koncepcji własnej. Ponadto oceniam, że realizacja przyjętej koncepcji stanowi dużą wartość, gdyż daje w efekcie tekst odpowiadający wszystkim standardom w przedmiotowym zakresie, a jednocześnie autentycznie oryginalny i korzystnie odróżniający się od innych znanych mi krajowych i zagranicznych opracowań z zakresu algebry liniowej. Na podkreślenie zasługuje też fakt, że przedstawiony do zaopiniowania tekst różni od pierwowzoru mnogość logicznych rozszerzeń i twórczych uzupełnień.

\section{Uwagi ogólne i szczegółowe}

Przedstawiony do zaopiniowania tekst podręcznika naukowego „Algebra liniowa” napisany przez Profesora Antoniego Smoluka jest oryginalnym, twórczym i całościowym opracowaniem naukowym dobrze określonego i precyzyjnie wyodrębnionego obszaru badawczego o istotnym zna- 
czeniu teoretycznym i utylitarnym, przy czym zarówno szczegółowy dobór przedstawionego materiału, jak i sposób realizacji przyjętych koncepcji ogólnych są silnie zindywidualizowane niebanalną osobowością Autora. W konsekwencji oceniam, że opiniowane dzieło jest nie tylko klasycznym akademickim podręcznikiem naukowym, lecz przede wszystkim znakomitą monografią naukową o dużym, ważkim interdyscyplinarnym znaczeniu naukowym.

Powyższe oceny ogólne przesądzają jednoznacznie i zdecydowanie, że pod względem merytorycznym opiniowane dzieło nie budzi mych zastrzeżeń, nie oznaczają natomiast, że nie mam żadnych uwag własnych do formy i treści niektórych fragmentów opiniowanej pracy. Tak więc obecnie przedstawię moje uwagi szczegółowe oraz spostrzeżenia krytyczne i polemiczne dotyczące recenzowanego tekstu. Dokonam tego w kilku oddzielnych punktach.

\section{Ocena zakresu tematycznego}

Stwierdzam, że obszar tematyczny opiniowanej monografii jest moim zdaniem oparty na $\mathrm{w}$ pełni poprawnych założeniach formalnych i merytorycznych, jest zgodny z odpowiednimi programami studiów ekonomicznych i pokrewnych oraz absolutnie odpowiada ewolucji pojęć i aktualnemu stanowi wiedzy w rozpatrywanym zakresie. Ponadto uważam, że recenzowane dzieło wyraźnie odróżnia się innych opracowań z przedmiotowego zakresu, które ukazały się dotąd w Polsce i, jak wynika z mojego rozeznania, jest bezprecedensowe również w skali międzynarodowej. Stanowi o tym oryginalny dobór prezentowanej tematyki oraz przyjęta i konsekwentnie realizowana autorska konwencja przedstawiania wybranych treści. Znakomity efekt końcowy Autor osiągnął, moim zdaniem, poprzez skoncentrowanie uwagi na starannym wyborze i perfekcyjnej prezentacji najistotniejszych znanych koncepcji w przedmiotowym zakresie oraz na konsekwentnym wprowadzaniu i forsowaniu na tym tle własnych, oryginalnych koncepcji naukowych filozoficznych i metodologicznych. Autor uzyskał przy tym rezultat końcowy budzącą respekt, niemal idealną równowagę pomiędzy czysto akademickimi rozważaniami formalnymi a interdyscyplinarną sferą aplikacyjną w przyjętym zakresie.

\section{Ocena kompozycji pracy}

Podział zasadniczej części opiniowanego dzieła Profesora Antoniego Smoluka na piętnaście rozdziałów jest w mej opinii w pełni merytorycznie 
uzasadniony. Proporcje między poszczególnymi rozdziałami uważam za sensowne i logicznie uzasadnione. Ponadto stwierdzam, że wszystkie wyróżnione oddzielne części tekstu przenikają się i uzupełniają się wzajemnie, a hierarchia, w jakiej następuje ich prezentacja, jest logiczna, uzasadniona i raczej nie do podważenia. Zwraca również uwagę niezwykła równowaga akcentów rozłożonych na poszczególne podjęte tematy. Układ i zakres treści w poszczególnych piętnastu merytorycznych częściach pracy także nie jest kontrowersyjny, gdyż jest on oparty na trwale ukierunkowanych standardach, a dodatkowo na szczególne wyróżnienie pod tym względem zasługuje w pełni oryginalny, autorski wybór szczegółów i rozkład akcentów pozwalający natychmiast odróżnić opiniowany podręcznik od innych opracowań tego typu, a nawet jednoznacznie zidentyfikować Autora na tle światowej literatury przedmiotu

\section{Ocena sposobu przedstawienia materiału}

Oceniam, że Autor nienagannie, swobodnie, bardzo sprawnie i zręcznie posługuje się jednocześnie dość skomplikowaną terminologią fachową i znakomicie włada pięknie ukształtowaną poprawną polszczyzną. Fakty, oceny, wnioski i rekomendacje formułowane są zawsze krótko i zwięźle, lecz jednocześnie absolutnie precyzyjnie i w pełni wyczerpująco. W konsekwencji stosowania przez Autora żywej i potoczystej narracji tekst jest przekonywający i komunikatywny, a tym samym czytany jest nadzwyczaj lekko, z autentyczną przyjemnością i poczuciem udziału w ważnym przedsięwzięciu intelektualnym.

\section{Ocena zastosowanej terminologii}

Cała terminologia, niemal wszystkie oznaczenia i symbole stosowane w opiniowanym tekście są na ogół standardowe, nie budzą zasadniczych wątpliwości i nie stanowią źródła kontrowersji, nieporozumień i istotnych niejasności. Tam, gdzie jest to merytorycznie uzasadnione, Autor wprowadza propozycje oryginalnych terminów polskojęzycznych i symboli. $\mathrm{Na}$ wyróżnienie zasługuje również fakt, że do tekstu wprowadzono, moim zdaniem, optymalną ilość fachowych terminów i oznaczeń. Oznacza to, że nie odczuwa się braku żadnej definicji i oznaczenia, a jednocześnie żadne stosowane określenie algebraiczne nie jest zbędne. 


\section{Ocena całkowitej objętości pracy}

Przedstawiony do zaopiniowania tekst pod względem jego obszerności oceniam jako optymalny $\mathrm{w}$ rozpatrywanym zakresie, gdyż jest rozsądnie zwięzły, a jednocześnie pełny i wyczerpujący. Ponadto redakcję tekstu nie waham się uznać za wzorową. Nie stwierdzam bowiem ani braków istotnych informacji, ani zbędnych powtórzeń, a korekty i uzupełnienia w stosunku do pierwowzoru uważam za istotne i trafne. Ponadto intuicyjnie odczuwam, że z tekstu emanuje autentyczny szacunek dla każdego potencjalnego czytelnika i użytkownika, przejawiający się konsekwentnym unikaniem taniego mentorstwa i przeeksponowania naukowości.

\section{Ocena doboru jakościowego elementów graficznych}

Uważam, że elementy graficzne w tekście są właściwie zredagowane, czytelne, dobrze wyselekcjonowane, starannie wykonane, na ogół niezbędne i znakomicie uzupełniają tekst główny. Sądzę jednak nadal, że Autor powinien dodatkowo zrewidować koncepcję numerowania rysunków tak, aby niektóre różne rysunki nie miały identycznych numerów.

\section{Postulaty i wskazówki dla Autora}

Uważna i z obowiązku bycia recenzentem krytyczna ocena przedstawionego tekstu skutkuje tym, że już we wcześniejszych fragmentach niniejszej opinii zgłosiłem uwagę o charakterze formalnym i redakcyjnych, której ewentualne uwzględnienie może wpłynąć na udoskonalenie jakości tekstu. Ponadto przedstawiam następujące dodatkowe postulaty dla Autora, których odpowiednie uwzględnienie lub pominięcie można, mym zdaniem, dodatkowo rozpatrzyć.

1. Uważam, że stronie 28 we wzorze $w$ ostatniej linii tekstu, pierwszy kwantyfikator powinien być ogólny, a nie szczegółowy.

2. W ostatnim wzorze na stronie 76 we wskazanym miejscy brak znaku równości.

3. Warto rozważyć uzupetnienie i skonkretyzowanie rysunku 3 i jego opisu na stronie 78.

4. Ostatni wiersz ze strony 101 powinien być przeniesiony na stronę 102.

5. Konieczne jest skorygowanie dwukrotnego wystepowania strony 135. 


\section{Wnioski końcowe}

Tekst podręcznika naukowego, o ewidentnym charakterze monografii naukowej, pt.: „Algebra liniowa” autorstwa Profesora Antoniego Smoluka, jest autentycznie twórczym rozszerzeniem i logicznym uzupełnieniem pierwowzoru, którym był wydany w roku 2007 przez Wydawnictwo Akademii Ekonomicznej we Wrocławiu podręcznik naukowy „Podstawy algebry liniowej” też napisany przez Profesora Antoniego Smoluka. W stosunku do pierwowzoru Autor dokonał licznych korekt i uzupełnień, w szczególności na stronach 19, 78, 78, 96, 116, 132-3, 201 oraz 222. Ponadto pewne fragmenty tekstu występujące w pierwowzorze w nowej edycji pominięto.

Finalnie, przedstawiony do recenzji tekst zawiera $\mathrm{w}$ pełni oryginalny opis szerokiego spektrum starannie dobranych, aktualnych problemów teoretycznych współczesnej algebry liniowej i związanych z nimi zagadnień aplikacyjnych, zwłaszcza o charakterze ekonomicznym. Autor, kierując się autentycznym profesjonalizmem, dokonał oryginalnego $\mathrm{i} w$ mej opinii trafnego wyboru kilkunastu szczegółowych zagadnień z przedmiotowego zakresu i umiejętnie połączył oddzielne nurty tematyczne w spójną i logiczną całość. Poszczególne zagadnienia szczegółowe oraz nadrzędna idea całości tekstu przedstawione $\mathrm{w}$ opiniowanym opracowaniu zaprezentowane są w sposób precyzyjny, wyczerpujący i jednocześnie, na ile to możliwe, przystępny i zrozumiały. Nie waham się też stwierdzić, że logika opiniowanej monografii naukowej rzuca nowe światło na przedmiotową tematykę. Tak więc recenzowany tekst jest dojrzałą i znakomicie zrealizowaną monografią naukową. Wynika to stąd, że recenzowane opracowanie cechuje oryginalna ogólna koncepcja naukowa przejawiająca się w spojrzeniu na rozpatrywaną problematykę z najwyższego dostępnego obecnie pułapu, odpowiadającego aktualnemu stanowi wiedzy światowej w rozpatrywanym zakresie.

Stwierdzam również, że przedstawiony do zaopiniowania tekst w pełni pokrywa obowiązujące wymagania programowe przedmiotów ilościowych, przede wszystkim algebry liniowej i matematyki, na studiach ekonomicznych. Tym samym podręcznik naukowy „Algebra liniowa” autorstwa Profesora Antoniego Smoluka może znakomicie odegrać rolę nowoczesnego podręcznika dla studentów uczelni ekonomicznych oraz będzie mógł być wykorzystywany również przez wszystkich innych pragnących zrozumieć istotę nauki i matematyki, a w szczególności przez studentów matematyki i nauczycieli w szkołach wszystkich szczebli. 
Przeto bez wahania i cienia wątpliwości stwierdzam, że recenzowany podręcznik naukowy - monografia naukowa wręcz powinien być opublikowany, ze względu na jego ponadprzeciętnie wysoki poziom naukowy, dydaktyczny i znaczenie utylitarne, w przedstawionej wersji, bez zmian w zakresie koncepcji ogólnej, lecz jednocześnie po zrewidowaniu i ewentualnym uwzględnieniu szczegółowych kwestii formalnych i redakcyjnych sformułowanych w niniejszej ocenie.

Katowice, 7.10.2016

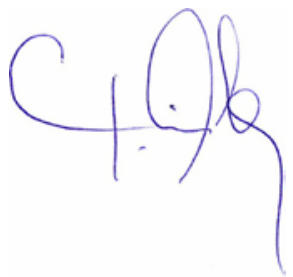

